\title{
Kualitas Laporan Keuangan Sebelum dan Sesudah Penerapan Aplikasi MYOB pada UD Keluarga di Kota Payakumbuh
}

\author{
Deni Saputra*, Putri Intan Permata Sari, Agam Mei Yudha \\ Universitas Putra Indonesia "YPTK" Padang \\ *Correspondence email: denisaputra@upiyptk.ac.id
}

\begin{abstract}
Abstrak. Penelitian ini bertujuan untuk mengetahui apakah aplikasi MYOB dapat digunakan sebagai alat bantu pencatatan laporan keuangan secara efektif dan efisien pada UD. Keluarga di Payakumbuh. Jenis data yang digunakan adalah data primer dan data sekunder. Metode analisis data yang dilakukan dalam penelitian ini adalah analisis deskriptif kualitatif dan analisis komparatif. Hasil penelitian ini menunjukkan bahwa dengan adanya sistem akuntansi berbasis komputer khususnya MYOB sangat membantu manajemen bisnis, karena laporan yang dihasilkan lebih up to date dan MYOB dapat meningkatkan kualitas informasi laporan keuangan dengan kecepatan, ketepatan, kelengkapan, dll. dapat menganalisis dengan jelas setiap transaksi di sana setiap hari. Penulis menyarankan kepada UD.Keluarga, untuk melakukan pencatatan semua transaksi yang terjadi kedalam MYOB sehingga dapat lebih meningkatkan keamanan dalam penyimpanan data dan perlu adanya pelatihan agar dapat menjalankan MYOB dan dapat sesuai dengan prinsip akuntansi sehingga dapat menyusun laporan keuangan secara tepat waktu dan dapat mengambil informasi dengan cepat.
\end{abstract}

Kata kunci: akuntansi MYOB; Komputer; Kualitas Informasi

Abstract. This study aims to determine whether the MYOB application can be used as a tool for recording financial statements effectively and efficiently at UD. Family in Payakumbuh. Jenis data used are primary data and secondary data. Method of data analysis conducted in this research is descriptive qualitative analysis and comparative analysis. The results of this study show that with the existence of computer-based accounting system, especially MYOB is very helpful business management, because the report produced more up to date and $M Y O B$ can improve the quality of financial statement information with speed, accuracy, completeness, etc. can clearly analyze each transaction there every day. The author suggests to UD. Family, to record all transactions that occur into $M Y O B$ so that it can further increase security in data storage and need training in order to run $M Y O B$ and be in accordance with accounting principles so that they can compile financial reports in a timely manner and can retrieve information quickly.

Keywords: Computer; $M Y O B$ accounting; Quality of Information

\section{PENDAHULUAN}

Pada zaman globalisasi ekonomi industri seperti saat sekarang ini, teknologi berkembang semakin pesat. Hal ini menjadi suatu tuntutan bagi semua perusahaan maupun kegiatan yang ada terutama pada perekonomian. Dengan mengingat daya saing semakin tinggi, perusahaan sudah mulai mengembangkan berbagai macam sistem yang berbasis teknologi terutama teknologi informasi. Oleh karena itu, menjadi sebuah tuntutan juga bagi para-para ahli komputer untuk mengembangkan ilmu dibidangnya.

Banyaknya solusi oleh pengembang software untuk sistem informasi akuntansi agar informasi yang dihasilkan lebih tepat, cepat dan akurat. Dengan adanya teknologi, semua bisa menjadi mudah dan apa yang dikerjakan menjadi tepat waktu. Pencatatan akuntansi secara manual pastilah memiliki banyak kelemahan terutama adalah waktu yang dibutuhkan cukup lama dan memerlukan tenaga banyak dan kebutuhan mengenai informasi kurang akurat (Astuti, 2013). Menurut (Pradiani, 2013), pemakaian perangkat lunak dipilih sesuai dengan visi pengguna yang bersifat masa depan untuk kemudian dijabarkan strateginya sesuai dengan visi pengguna.
Perusahaan- perusahaan besar banyak yang menggunakan sistem komputerisasi karena telah banyak manfaatnya, sehingga mendorong perusahaan melakukan transisi dari sistem akuntansi manual ke sistem komputerisasi. Di dalam perusahaan, laporan keuangan akan pasti dihasilkan. Suatu perusahaan dapat dilihat dari hasil informasi untuk dikatakan mengalami kemajuan atau tidak, jadi keakuratan dalam kualitas laporan keuangan merupakan hal yang sangat penting untuk menyediakan suatu informasi yang dapat dijadikan untuk pengambilan keputusan untuk masa yang akan datang (Salim, 2019). Sistem komputerisasi ini memerlukan suatu software yang dirancang untuk menyajikan laporan keuangan dan informasi yang berkaitan dengan akuntansi. Salah satu software yang banyak digunakan adalah MYOB (Dewi, 2013).

MYOB (Mind Your Own Business) merupakan program aplikasi komputer yang digunakan sebagai aplikasi otomatis pembukuan yang mudah dan mampu menampilkan laporan keuangan secara lengkap, cepat dan akurat (Triantoro, 2012). Dengan adanya aplikasi akuntansi seperti MYOB, penyusunan laporan keuangan menjadi mudah, akuran dan kualitas laporan keuangan untuk menyediakan informasi menjadi lebih akurat dan 
tentunya memenuhi kriteria standar akuntansi keuangan dan kesalahan dalam proses penyusunan laporan keuangan dapat diminimalisir (Murni, 2020). Menurut

Menurut PSAK 1 (Revisi 2009) dalam (Yadiati, 2017) tentang Penyajian Laporan Keuangan mendefinisikan laporan keuangan sebagai suatu penyajian terstruktur dari posisi keuangan dan kinerja suatu entitas.

Menurut (Hery, 2015), Laporan keuangan merupakan hasil dari proses akuntansi yang dapat digunakan sebagai alat untuk mengkomunikasikan data keuangan atau aktivitas perusahaan kepada pihak-pihak yang berkepentingan.

Menurut (Wahyudiono, 2014), Laporan Keuangan merupakan alat komunikasi utama perusahaan. Laporan keuangan yang dibuat oleh perusahaan menggambarkan hasil usaha perusahaan dalam suatu periode tertentu. Dalam laporan laba rugi ini tergambar jumlah pendapatan dan sumber-sumber pendapatan yang diperoleh. Kemudian tergambar jumlah biaya dan jenisjenis biaya yang dikeluarkan selama periode tertentu (Kasmir, 2016). Setiap perusahaan memiliki bidang usaha dan karakteristik yang berbeda satu dengan yang lainnya, sehingga rincian laporan keuangan satu perusahaan dengan perusahaan lainnya juga berbeda. Namun, laporan keuangan yang dihasilkan oleh setiap institusi harus memenuhi beberapa standar kualitas seperti yaitu dapat dipahami, relevan, materialitas, keandalan, kelengkapan, dapat dibandingkan, dan tepat waktu (Rudianto, 2012)

Menurut (Hery, 2015) Tujuan laporan keuangan untuk organisasi pencari laba (Profit Organization), adalah Memberikan informasi yang berguna bagi investor, kreditor, dan pemakai lainnya dalam membuat keputusan secara rasional mengenai investasi, kredit, dan lainnya.

Laporan keuangan yang dibuat oleh perusahaan menggambarkan hasil usaha perusahaan dalam suatu periode tertentu. Dalam laporan laba rugi ini tergambar jumlah pendapatan dan sumber-sumber pendapatan yang diperoleh. Kemudian tergambar jumlah biaya dan jenisjenis biaya yang dikeluarkan selama periode tertentu.

Pengolahan data akuntansi menggunakan MYOB hanya memerlukan tahapan proses, Langkahnya sepertinya panjang dalam penulisan teori, tetapi praktis dalam praktiknya. Prinsipnya MYOB hanya sampai pencatatn jurnal khusus, setelah itu semua laporan otomatis, termasuk buku besar dan penyusunan naraca saldonya (Zaenuri, 2013).

Menurut (Lubis, 2016), Keunggulan MYOB Accounting yaitu diantaranya mudah dimengerti dan dipelajari oleh pengguna, dapat langsung dioperasikan bagi usaha bisnis di Indonesia, dan hamper $100 \%$ memenuhi Standar Akuntansi Keuangan (SAK)

Hasil penelitian yang dilakukan oleh (Sapitri et al., 2016) bahwa pemanfaatan teknologi informasi berpengaruh positif dan signifikan terhadap kualitas laporan keuangan, dan hasil penelitian yang dilakukan oleh (Rahardja et al., 2018) bahwa dengan adanya Software Jurnal (Software Akuntansi Online) dinilai dapat mempermudah akuntan dalam menginput data transaksi ke dalam sistem, di mana data transaksi tersebut dapat langsung di import ke dalam sistem sehingga lebih efisien. Penelitian yang dilakukan oleh (Dewi, 2013) yang hasilnya bahwa pengolahan data elektronik dengan program MYOB pada UD. Widya Pratama dinilai sudah sangat efektif. Hal ini terlihat dari hasil efektivitas yang diukur melalui empat indikator yaitu keamanan data dengan hasil efektivitas $86 \%$, waktu dengan hasil efektivitas 88,8\%, keakuratan dengan hasil efektivitas $88 \%$, dan relevansi dengan hasil analisis efektivitas $87,2 \%$. Seluruh indikator berada pada kategori sangat efektif.

UD. Keluarga merupakan salah satu usaha dagang yang bergerak dibidang penjualan telur ayam dan penjualan ayam afkir yang terletak di kelurahan tanah mati Unggas salah satu komoditi unggulan sumbar. Potensinya sangat besar, terdiri dari ayam ras baik ayam petelur maupun ayam potong, ayam lokal, itik dan puyuh. Sebagian besar masyarakat sumbar sudah menggeluti usaha berternak ayam.

Produk utama yang dihasilkan adalah ayam dan telur. Untuk ayam dan telur akan langsung dijual pada para agen pedagang ayam dan telur yang akan dibawa keluar kota dan juga bisa dijual di pasaran daerah.

Ayam ras petelur adalah jenis ayam unggul yang induk atau nenek moyangnya merupakan ayam impor yang telah mengalami perbaikan genetik melalui proses persilangan dan seleksi dengan tujuan produksi sebagai penghasil telur.

Hal tersebut berdasarkan pendapat dari (Rahayu, 2012), bahwa ayam ras adalah ayam yang induk atau nenek moyangnya merupakan ayam impor. Sedangkan ayam tipe petelur adalah ayam yang dapat menghasilkan relative banyak telur dalam waktu yang singkat.

Suprijatun (2016) mendefinisikan ayam ras sebagai jenis ayam dari luar negeri yang bersifat unggul sesuai dengan tujuan pemeliharaan karena telah mengalami perbaikan mutu genetik.

Secara spesifik, (Rasyuf, 2013) menyebutkan ayam ras yang terseleksi untuk tujuan produksi telur dikenal dengan ayam petelur. Persilangan dan seleksi dilakukan cukup lama hingga menghasilkan ayam petelur seperti sekarang. Dalam setiap persilangan, sifat jelek selalu dibuang dan sikap baik akan dipertahankan, sehingga terciptalah ayam petelur unggul.

Selama ini sistem pengendalian intern perusahaan belum mengoptimalkan pengolahan data dan informasi dengan menggunakan pemanfaatan kemajuan teknologi informasi. Saat ini UD. Keluarga masih menggunakan sistem perhitungan secara manual dalam proses pencatatan dan perhitungan kas keluar masuk. Namun pengolahan data yang selama ini dilakukan secara sederhana masih belum dirasa maksimal, sehingga 
Deni Saputra, Putri Intan Permata Sari dan Agam Mei Yudha, Kualitas Laporan Keuangan Sebelum dan Sesudah Penerapan Aplikasi MYOB pada UD Keluarga di Kota Payakumbuh

kualitas laporan keuangan kurang efektif dan efisien. Tujuan penelitian dilakukan untuk mengetahui apakah aplikasi MYOB dapat digunakan sebagai alat bantu pencatatan laporan keuangan secara efektif dan efisien pada UD. Keluarga di Payakumbuh

\section{METODE}

\section{Teknik analisis data}

Analisis Kualitatif Deskriptif, yaitu dengan cara mendeskripsikan atau menggambarkan keadaan Usaha Ayam Ras (Petelur) yang sesungguhnya, untuk mengetahui dan menganalisis permasalahan yang sedang dihadapi objek penelitian.

Analisis Komparatif yaitu dengan cara membandingkan laporan keuangan yang dibuat oleh Usaha Ayam Ras (Petelur) dengan laporan yang tersusun berdasarkan penerapan Aplikasi Komputer MYOB.

\section{Metode penganalisaan data}

Metode statistik diskriptif (Sugiyono, 2014) Statistik deskriptif digunakan untuk menganalisis data dengan cara mendeskripsikan atau mengambarkan data yang telah terkumpul sebagaimana adanya tanpa bermaksud membuat kesimpulan yang berlaku untuk umum dan generalisasi.

Metode komparatif (Sugiyono, 2016) digunakanuntuk membandingkan keberadaan satu variabel atau lebih pada dua atau lebih sampel yang berbeda, atau pada waktu yang berbeda.

\section{HASIL DAN PEMBAHASAN}

Laporan keuangan manual UD. Keluarga bulan Juni tahun 2017 dapat dilihat sebagai berikut:

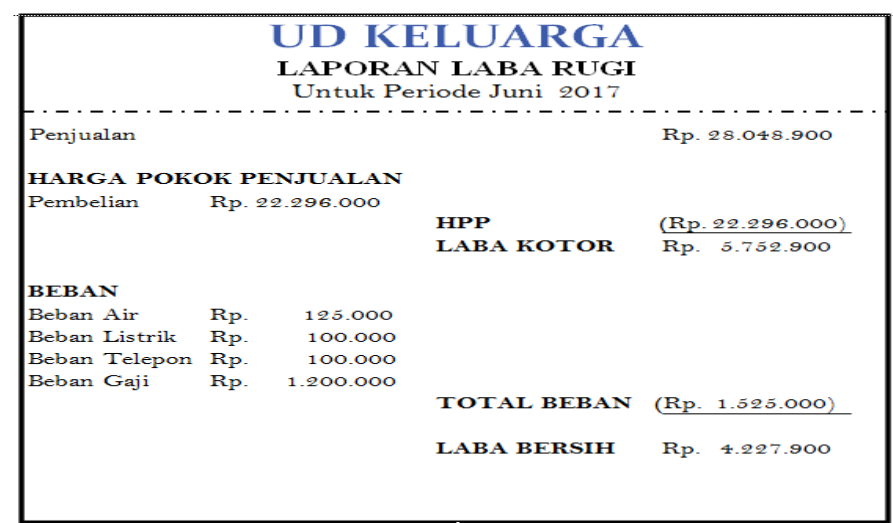

Gambar 1. Laporan laba rugi periode juni 2017

Berdasarkan laporan laba rugi UD. Keluarga dijelaskan sebelumnya bahwa penjualan sebesar Rp. 28.048.900. pada tahun 2017. Dengan adanya pengeluaran atas beban-beban pada bulan juni tahun 2017 sebesar Rp. 1.525.000, maka UD. Keluarga memperoleh laba sebesar Rp. 4.227.900.

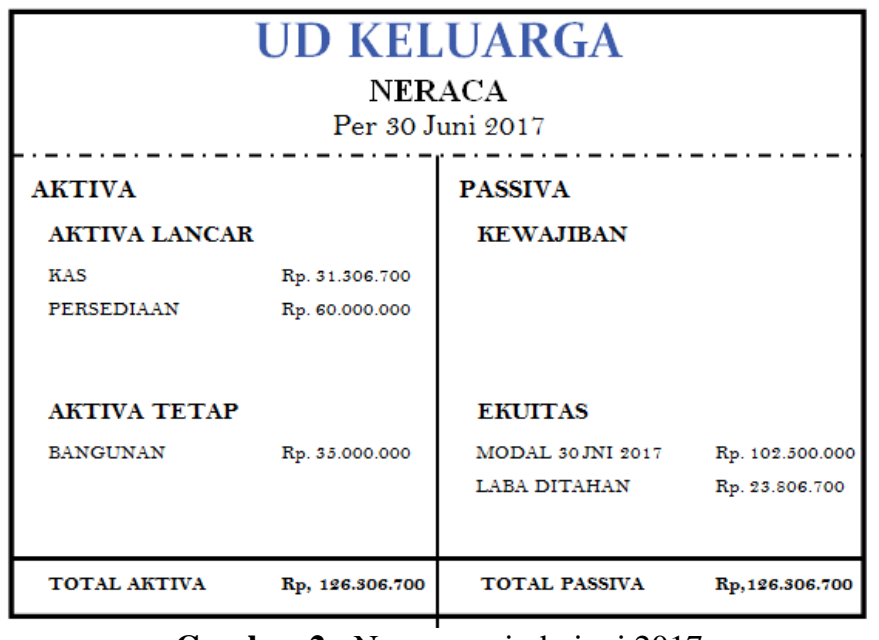

Gambar 2. Neraca periode juni 2017

Penyajian laporan neraca UD. Keluarga di bulan juni terdapat kas sebesar Rp.31.306.700, persediaan Rp. 60.000.000 dan bangunan sebesar Rp. 35.000.000 dan passiva sebesar Rp. 126.306.700

Pencatatan laporan keuangan dengan menggunakan aplikasi komputer MYOB dapat dilihat outputnya pada gambar dibawah ini:

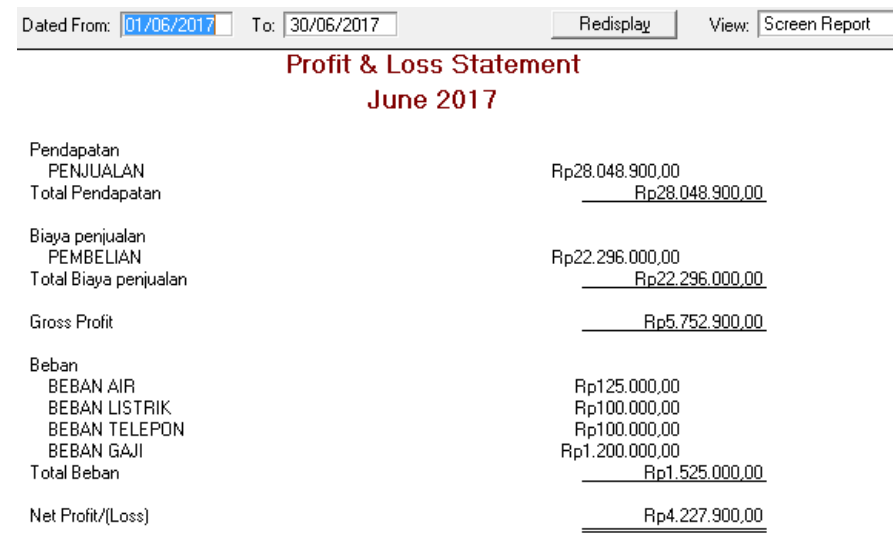

Gambar 3. Laporan laba rugi periode juni 2017

\begin{tabular}{|c|c|c|}
\hline As of $30 / 06 / 2017$ & Redisplay & View: Screen Rer \\
\hline & & \\
\hline $\begin{array}{l}\text { Aset } \\
\text { KAS } \\
\text { PERSEDIAAN AYAM } \\
\text { BANGUNAN } \\
\text { Total A Aset }\end{array}$ & \multicolumn{2}{|c|}{$\begin{array}{l}\text { Rp } 31.306 .700,00 \\
\operatorname{Rp} 60.000 .000,00 \\
\text { Rp } 35.000 .000,00 \\
\text { Rp } 226.306 .700,00\end{array}$} \\
\hline Hutang & & \\
\hline Net Assets & & Rp126.306.700,00 \\
\hline $\begin{array}{l}\text { Modal } \\
\text { MODAL } \\
\text { Laba ditahan } \\
\text { Total Modal }\end{array}$ & 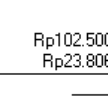 & $\begin{array}{l}\frac{000,00}{7000.00} \\
\mathrm{Fp} 126.306 .700,00\end{array}$ \\
\hline
\end{tabular}

Gambar 4. Neraca periode juni 2017

\section{Perbandingan kualitas laporan keuangan}

Berdasarkan pencatatan laporan keuangan usaha telur ayam ras UD. Keluarga antara pencatatan secara manual dengan menggunakan komputerisasi akuntansi 
Deni Saputra, Putri Intan Permata Sari dan Agam Mei Yudha, Kualitas Laporan Keuangan Sebelum dan Sesudah Penerapan Aplikasi MYOB pada UD Keluarga di Kota Payakumbuh

MYOB dapat dibandingkan dan dilihat bahwa jika pencatatan dilakukan secara manual, maka pencatatan dibutuhkan waktu yang lama dan akan rentan terjadinya kesalahan, sehingga pemilik usaha pun bahkan tidak mengetahui kesalahan pencatatan tersebut, sehingga kualitas laporan keuangan tidak efektif dan efisien.

Jika dilihat dari pencatatan menggunakan komputer akuntansi MYOB, dapat dilihat bahwa laporan yang dihasilkan lebih efektif dan efisien dan terlihat jelas pada masing-masing transaksi. Hasil penelitian ini sejalan dengan penelitian (Sapitri et al., 2016) bahwa pemanfaatan teknologi informasi berpengaruh positif dan signifikan terhadap kualitas laporan keuangan, dan hasil penelitian yang dilakukan oleh (Rahardja et al., 2018) bahwa dengan adanya Software Jurnal (Software Akuntansi Online) dinilai dapat mempermudah akuntan dalam menginput data transaksi ke dalam sistem, di mana data transaksi tersebut dapat langsung di import ke dalam sistem sehingga lebih efisien. Penelitian yang dilakukan oleh (Dewi, 2013) juga sejalan yang hasilnya bahwa pengolahan data elektronik dengan program MYOB pada UD. Widya Pratama dinilai sudah sangat efektif. Hal ini terlihat dari hasil efektivitas yang diukur melalui empat indikator yaitu keamanan data dengan hasil efektivitas $86 \%$, waktu dengan hasil efektivitas $88,8 \%$, keakuratan dengan hasil efektivitas $88 \%$, dan relevansi dengan hasil analisis efektivitas $87,2 \%$. Seluruh indikator berada pada kategori sangat efektif. Dengan menggunakan aplikasi komputer akuntansi MYOB ini, lebih meningkatkan kualitas laporan keuangan karena prosesnya cepat secara otomatis. dan pemilik usaha dapat dengan mudah menyajikan laporan keuangan kapanpun kepada pihak yang membutuhkan informasi.

\section{SIMPULAN}

Dengan adanya sistem akuntansi berbasis komputer, khususnya program MYOB sangat membantu manajemen, karena laporan yang dihasilkan oleh MYOB bersifat up to date disebabkan karena prosesnya yang dilakukan secara otomatis sehingga dapat dilihat dan dicetak kapan saja sesuai dengan kebutuhan dan keinginan pemilik.

Dengan MYOB dapat meningkatkan kualitas laporan keuangan pada Usaha Telur Ayam Ras UD. Keluarga dengan kecepatan, ketepatan, kelengkapan,kemudahan, keamanan, maupun volume yang dihasilkan lebih detail sehingga penyajian laporan keuangan menjadi efektif dan efisien dan pemilik dapat dengan jelas menganalisa setiap transaksi yang ada setiap harinya.

\section{DAFTAR PUSTAKA}

Astuti. (2013). Evaluasi Sistem Informasi Akuntansi Pengendalian Kas Berbasis Komputer Pada Perusahaan Internet Service Provider (STUDI KASUS PENERAPAN APLIKASI MYOB V 13+
DI PT.LDP YOGYAKARTA). Jurnal Akuntansi Dan Pendidikan, 2(April), 18-24.

Dewi, P. (2013). ANALISIS EFEKTIVITAS PENGOLAHAN DATA ELEKTRONIK. Universitas Pendidikan Ganesha.

Hery. (2015). Pengantar Akuntansi Comprehensive Edition. Jakarta: PT. Grasindo.

Hery. (2015). Praktis Menyusun Laporan Keuangan. Jakarta: PT. Grasindo.

Kasmir. (2016). Analisis Laporan Keuangan. Jakarta: Raja Wali Pers.

Lubis, R. H. (2016). Penyusunan Laporan Keuangan dengan Myob V.19. Jakarta: PT. Grasindo.

Murni, S. (2020). Peningkatan Kualitas Laporan Keuangan Dengan Software MYOB Accounting Versi $16 . \quad 01(01), \quad 31-39$. https://ejournal.bsi.ac.id/ejurnal/index.php/justian/ article/view/7985

Pradiani. (2013). Komparasi kinerja aplikasi komputer akuntansi myob v.17 dan accurate v.4 pada proses penyelesaian transaksi pembelian dan penjualan. Fakultas Teknologi Informasi Universitas Merdeka Malang, 208-217.

Rahardja, U., Aini, Q., \& Hardini, M. (2018). Penerapan Software Akuntansi Online Sebagai Penunjang Pencatatan Laporan Keuangan. Sisfotenika, 8(2), 176. https://doi.org/10.30700/jst.v8i2.408

Rahayu, dkk. (2012). Definisi Ayam Ras (Edisi 3). Institut Pertanian Bogor.

Rasyuf, dkk. (2013). Definisi Ayam Ras (Ed 5, ct 3). Institut Pertanian Bogor.

Rudianto. (2012). Pengantar Akuntansi. Jakarta: Erlangga Adaptasi IFRS.

Salim, E. (2019). Pengaruh Penerapan Penggunaan Softaware Akuntansi ( MYOB Accounting) Dalam Upaya Mempermudah Dan Mengefisienkan Kinerja Pelaporan Keuangan Pada Perusahaan. Jurnal EKOBISTEK Fakultas Ekonomi, 8(1), 92-101. http://lppm.upiyptk.ac.id/ojsupi/index.php/EKOBI STEK/article/view/186/128

Sapitri, N. M. T., Purnamawati, i G. A., \& Sujana, E. (2016). Pengaruh Kapasitas Sumber Daya Manusia, Pengendalian Internal Akuntansi, dan Pemanfaatan Teknologi Informasi Terhadap Kualitas Laporan Keuangan (Studi Kasus Koperasi Simpan Pinjam Di Kecamatan Buleleng). E-Journal S1 Ak Universitas Pendidikan Ganesha, 3(1), 1.

Sugiyono. (2014). Cara Mudah Menyusun Skripsi,Tesis dan Disertasi. Bandung: Alfabeta.

Sugiyono. (2016a). Metode Penelitian Pendidikan.

Sugiyono. (2016b). Metode Penelitian Pendidikan Pendekatan Kuantitatif, Kualitatif, Dan $R \& D$. Bandung : Alfabeta.

Suprijatun. (2016). Definisi Ayam Ras (Ed 3, ct 1). Institut Pertanian Bogor. 
Deni Saputra, Putri Intan Permata Sari dan Agam Mei Yudha, Kualitas Laporan Keuangan Sebelum dan Sesudah Penerapan Aplikasi MYOB pada UD Keluarga di Kota Payakumbuh

Triantoro, A. (2012). MYOB V.18. yogyakarta: CV. Andi Offset.

Wahyudiono, B. (2014). Mudah Membaca Laporan Keuangan. Yogyakarta: Raih Asa Sukses.

Yadiati, W. (2017). Kualitas Pelaporan Keuangan: Kajian Teoritis dan Empiris. Jakarta: Kencana.

Zaenuri. (2013). PENERAPAN APLIKASI SOFTWARE MYOB PADA PERUSAHAAN DAGANG ( TOKO ANGKASA KOMPUTER ) Mochamad Zaenuri. Jurnal AMIK JTC Semarang, 2. 